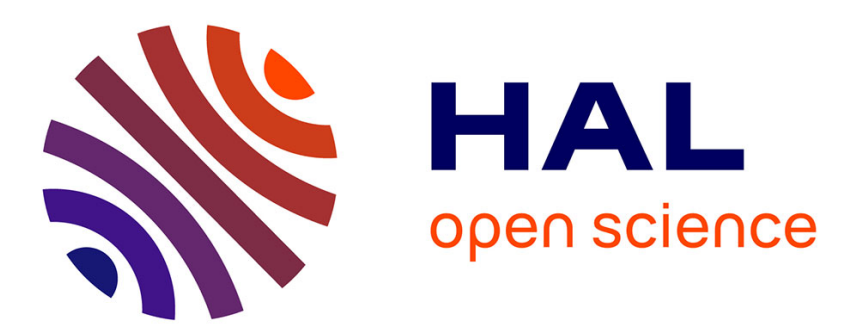

\title{
Deleterious effects of a nonPST bioactive compound(s) from Alexandrium tamarense on bivalve hemocytes
}

Susan E. Ford, V. Monica Bricelj, Christophe Lambert, Christine Paillard

\section{To cite this version:}

Susan E. Ford, V. Monica Bricelj, Christophe Lambert, Christine Paillard. Deleterious effects of a nonPST bioactive compound(s) from Alexandrium tamarense on bivalve hemocytes. Marine Biology, 2008, 154, pp.241-253. 10.1007/s00227-008-0917-z . hal-00461303

\section{HAL Id: hal-00461303 https://hal.science/hal-00461303}

Submitted on 4 Mar 2010

HAL is a multi-disciplinary open access archive for the deposit and dissemination of scientific research documents, whether they are published or not. The documents may come from teaching and research institutions in France or abroad, or from public or private research centers.
L'archive ouverte pluridisciplinaire HAL, est destinée au dépôt et à la diffusion de documents scientifiques de niveau recherche, publiés ou non, émanant des établissements d'enseignement et de recherche français ou étrangers, des laboratoires publics ou privés. 


\title{
Deleterious effects of a nonPST bioactive compound(s) from Alexandrium tamarense on bivalve hemocytes
}

\author{
Susan E. Ford; V. Monica Bricelj; Christophe Lambert; Christine Paillard
}

S. E. Ford $(\triangle)$ : Haskin Shellfish Research Laboratory, Rutgers University, 6959 Miller Avenue, Port Norris, NJ 08349, USA. E-mail: susan@hsrl.rutgers.edu

V. M. Bricelj: National Research Council, Institute for Marine Biosciences, 1411 Oxford Street, Halifax, NS B3H 3Z1Canada.

C. Lambert, C. Paillard : Institut Universitaire Européen de la Mer, LEMAR, UMR CNRS 6539, Place Copernic, Site Technopôle Brest Iroise, 29280 Plouzané, France.

\begin{abstract}
The known negative effects of shellfish toxin producing dinoflagellates on feeding, burrowing and survival of some bivalve mollusks has prompted questions concerning whether they might also impair the internal defense system of affected bivalves and make them more susceptible to disease agents. The primary components of the cellular defense system are hemocytes. Many toxic dinoflagellates are too large to be ingested whole by hemocytes and would most likely be exposed to intracellular toxins only after the algae are consumed, broken down, and the water-soluble toxins, released. Therefore, we conducted a series of experiments in which hemocytes from two suspension-feeding bivalves - the Manila clam, Ruditapes philippinarum, and the softshell clam, Mya arenaria - were exposed in vitro to filtered extracts of one highly toxic paralytic shellfish toxin (PST)-producing and one nonPST-producing strain of Alexandrium tamarense (isolates PR18b, $76 \pm 6$ STXeq cell $^{-1}$ ) and CCMP115, with undetectable PST, respectively). We measured adherence and phagocytosis, two hemocyte attributes known to be inhibited by bacterial pathogens and other stressors. We found no measurable effect of a cell-free extract from a highly concentrated suspension of the PSTproducing strain on hemocytes of either bivalve species. Instead, extract from the nonPST-producing strain had a consistent negative effect on both clams, resulting in significantly lower adherence and phagocytosis compared to strain PR18b and filtered seawater controls. The bioactive compound produced by strain CCMP115, which has yet to be characterized, may be similar to the PST-independent allelopathic compounds described for Alexandrium spp., which act on other plankters. These compounds and those produced by other harmful algae are known to cause immobilization, cellular deformation and lysis of co-occurring target organisms. Thus, nonPST producing Alexandrium spp., which do not cause paralysis and burrowing incapacitation of clams, may still produce a compound(s) that has negative effects not only on hemocytes, but on other molluscan cell types and their functions, as well.
\end{abstract}

\section{Introduction}

Suspension-feeding bivalve mollusks act as primary vectors for a variety of toxins produced by algal species. The toxins, which are concentrated by the bivalves as they feed during algal blooms, pose a serious health risk to human consumers (Shumway 1990). Paralytic shellfish toxins (PSTs), produced by Alexandrium spp. in temperate waters, not only cause paralytic shellfish poisoning (PSP) in the human consumers of bivalves, but can also harm the mollusks themselves depending on their nerve susceptibility to these toxins. Exposure to high concentrations of PST-producing dinoflagellates can impair feeding, burrowing, and survival of affected bivalves (Shumway 1990).

The deleterious effect of PSTs and other shellfish toxins on certain bivalves has led investigators to question whether exposure to such compounds might also impair the internal defense, or immune, system of affected mollusks, making them more susceptible to disease and other environmental stressors. To investigate this possibility, an in vivo study assayed hemocytes, or blood cells, of oysters, Crassostrea gigas and C. virginica, using whole cells of PST-producing Alexandrium spp. of putative low to moderate toxicity; however, toxicity was not measured in parallel at the time of bivalve feeding experiments (Hégaret et al. 2007). The effects were minor or not measurable. Two other in vivo studies found some effects on hemocytes of $C$. virginica and bay scallops, Argopecten irradians, exposed to the non PST-producing toxic dinoflagellate Prorocentrum minimum for up to 7 days (Hégaret and Wikfors 2005a, b). Hemocyte numbers increased in most trials, but results measured for other parameters were highly variable. Paralytic shellfish toxins are water-soluble, endogenous compounds that are not readily released into the dissolved phase by intact Alexandrium spp. cells. This contrasts with toxic algae such as Pseudonitzschia spp., which can release high levels of domoic acid into the culture medium (Cusack et al. 2002). Paralytic shellfish toxins are comprised of about two dozen analogues that vary widely in specific toxicity, including three main groups: the $N$-sulfocarbamoyl (C and B) toxins of lowest 
potency, decarbamoyl toxins, and carbamate toxins. Carbamate toxins include saxitoxin (STX), the most potent derivative, as well as neosaxitoxin (NEO) and gonyautoxins (GTX1-GTX4) (Oshima 1995). Alexandrium spp. at $\sim 20$ to $35 \mu \mathrm{m}$ in diameter, are too large to be ingested by molluscan hemocytes, which average $\cdot 12 \mu \mathrm{m}$ in diameter (Cheng 1981). Hence, in vivo, hemocytes would probably come into contact with PSTs only after the algae have been consumed and digested, and the toxins released. This would most likely occur in the digestive tract, where hemocytes move back and forth through the epithelium of the gut, ingesting and transporting nutrients (Owen 1966). In addition, the chemically characterized toxins themselves are not the only noxious compounds produced by algae. Allelopathic compounds, which have negative effects on planktonic competitors and grazers are also produced (Arzul and Gentien 2006; Tillmann et al. 2007), as are ichthyotoxins that are noxious to fish. Algae that produce allelopathic compounds may or may not also produce shellfish toxins, and vice versa (Sugg and VanDolah 1999; Tillmann and John 2002; Lundholm et al. 2005). The production of algal ichthyotoxins by Alexandrium spp. also may be independent of PSTs. Thus, ichthyotoxicity leading to death of fingerling sea bass was demonstrated for an Asian strain of A. leei that contained no detectable PSTs (Tang et al. 2007).

The susceptibility of bivalves to PSTs varies widely among species (reviewed by Bricelj and Shumway 1998) and even between populations of a single species (Twarog et al. 1972; Shumway and Cucci 1987; Bricelj et al. 2005). The softshell clam, Mya arenaria, and the Manila clam, Ruditapes philippinarum, are two bivalves that have been introduced into France. Mya arenaria became extinct in European waters during the last glaciation, and was reintroduced by man from America to Europe as early as the 14th century (Behrends et al. 2005). Ruditapes philippinarum, a native of the western Pacific that was accidentally brought to the western United States in shipments of oysters, was deliberately introduced from there to France for aquaculture purposes in the 1970s (Flassch and Leborgne 1992). Both species are capable of accumulating relatively high levels of PSTs, up to two orders of magnitude above the $80 \mu \mathrm{g}$ saxitoxin equivalents (STXeq) $100 \mathrm{~g}^{-1}$ regulatory level for human consumption (Bricelj and Shumway 1998). Genetically based, intraspecific variability in toxin sensitivity and thus in the capacity for toxin accumulation has been demonstrated and ascribed to a natural, single point mutation in the Domain II pore region of the sodium ( $\mathrm{Na}+$ ) channel (Bricelj et al. 2005). Populations of $M$. arenaria that had experienced repeated exposure to blooms of the PSTproducing dinoflagellate, Alexandrium spp. were highly resistant to the effects of A. tamarense compared to clams from an area with no PSP history. However, the status of the $M$. arenaria populations originating from clams introduced into France was unknown at the time of the present study, as was that of $R$. philippinarum populations.

Blooms of PST-producing A. minutum are known to have occurred along much of the Atlantic coast of France since the late 1980s, and tend to show higher annual prevalence along the NW coast of Brittany (Réseau National de Surveillance du Phytoplancton et des Phycotoxines (REPHY), http://www.ifremer.fr/envlit/surveillance/rephy. htm). Although A. minutum isolates tested to date show relatively low PSP toxicity, typically ca. $2.4 \mathrm{pg} \mathrm{STXeq} \mathrm{cell}^{-1}$ (Bougrier et al. 2001), densities of up to 6,300 cells $\mathrm{ml}^{-1}$ have been reported in the Baie de Morlaix, northern Brittany, potentially leading to high concentrations of PSTs in the water column (http://www.ifremer.fr/ envlit/surveillance/rephy.htm). The geographic range of PSTproducing dinoflagellates has increased worldwide over past decades (Hallegraef 1993). Since the late 1990s, blooms of PST-producing A. catenella, have appeared in the Thau Lagoon on the Mediterranean coast of France (Lilly et al. 2002) where local isolates attain toxicities ranging from 5 to 15 pg STXeq cell ${ }^{-1}$ (Séchet et al. 2004). The objectives of the present work were twofold: (1) to measure the effects of in vitro, short-term exposure of hemocytes from French populations of the two clam species to cell-free extracts from PST and nonPSTproducing strains of the dinoflagellate, Alexandrium tamarense, and (2) to assess the possibility of using a hemocyte-based in vitro assay as a rapid test for effects of harmful algal blooms on mollusks. Because of the potential for individual variation in response to PSTs, we assayed hemocytes in hemolymph from individual clams as well as pooled samples.

\section{Materials and methods}

Experimental design

A series of five experiments was conducted in which hemocytes from $M$. arenaria and R. philippinarum were incubated in vitro with extracts from a PST-producing (PR18b) and a nonPST-producing (CCMP115) strain of $A$. tamarense. Two indices of hemocyte function were measured by flow cytometry: adherence and phagocytosis. Hemocytes typically are able to adhere strongly to glass or plastic surfaces, but when exposed to toxin-producing bacteria or other stressors, they become rounded and detach. The proportion of nonadherent hemocytes provides an index of the relative pathogenicity of bacteria (Choquet et al. 2003) and also the "health" of the hemocytes (Hégaret et al. 2004). Phagocytosis of foreign bodies is probably the most important defense activity of hemocytes and their ability to ingest abiotic particles such as fluorescent beads is routinely used as a measure of phagocytic capacity (Alvarez et al. 1989; Ordas et al. 1999; Allam et al. 2002; Soudant et al. 2004). 
Nonaxenic stock cultures were air-shipped to the Institut Universitaire Européen de la Mer (IUEM), near Brest, France from the Institute for Marine Biosciences, National Research Council (IMB/NRC), Canada. The toxic strain PR18b, isolated from the estuary of the Gulf of St Lawrence, Canada, was selected because of its high cellular toxicity as well as the fact that considerable information is available on the in vivo responses of bivalves, including Mya arenaria, to this strain (e.g., Bricelj and Shumway 1998, and references therein; Bricelj et al. 2005). Its mean equivalent spherical diameter (ESD) as determined with a Beckman Coulter Multisizer was 30.1 $\mu \mathrm{m}$. The non-PSP producing strain (CCMP115, $34.6 \mu \mathrm{m}$ ESD), isolated from the Tamar Estuary, Plymouth, England, was obtained from the Provasoli-Guillard National Center for Culture of Marine Phytoplankton (CCMP), Bigelow Laboratory for Ocean Sciences, West Boothbay Harbor, Maine, USA. The two Alexandrium spp. were batch cultured at $14 \pm 1^{\circ} \mathrm{C}$ and $35 \%$ o salinity with a $14 \mathrm{~h}: 10 \mathrm{~h}$ light:dark cycle, in 2-L glass flasks without aeration, using a modified $\mathrm{L} 1$ medium with the addition of $\mathrm{NH} 4 \mathrm{Cl}$ at a final concentration of $5 \times 10^{-5} \mathrm{M}$ (Guillard and Hargraves 1993). Seawater was $0.22-\mu \mathrm{m}$ filtered and sterilized by microwaving using a protocol adapted from Keller et al. (1988). The nutrients were autoclaved separately before addition to the medium under a laminar hood and the final $\mathrm{pH}$ checked to ensure that it remained below 8. Cultures were harvested in late exponential growth phase. Toxin was extracted from dinoflagellate cells on the same day that each trial was conducted. Culture densities were determined microscopically and cells concentrated by passing them through a $20-\mu \mathrm{m}$ Nitex screen. The retained dinoflagellates were resuspended in $0.22-\mu \mathrm{m}$ filtered seawater (FSW) in $15-$ $\mathrm{mL}$ centrifuge tubes. The cells were then centrifuged for $10 \mathrm{~min}$ at $4{ }^{\circ} \mathrm{C}$ and $2,800 \mathrm{xg}$, the supernatant removed, and the pellet again resuspended in $\sim 3 \mathrm{~mL}$ of filtered seawater $(\mathrm{pH} 7)$ to achieve a final concentration of $5 \times 105$ cells $\mathrm{mL}^{-1}$. The suspension was then probe-sonicated on ice to extract PSTs and the homogenates checked under the microscope to ensure complete cell breakage. The extract (containing dissolved PSTs and other metabolites released by cell breakage) was again centrifuged to remove particulate debris and the supernatant syringe-filtered through a $26-\mathrm{mm}$ diameter $0.45-\mu \mathrm{m}$ cellulose acetate membrane filter (Minisart, Sartorius, Aubagne, France) and maintained on ice until it was added to the well plates containing hemocytes. A slightly acidic $\mathrm{pH}(\sim 5)$ is typically recommended for long-term storage of PST extracts to maintain the integrity of individual toxins. Since the extracts were not prepared in an acidic solution to avoid unknown effects of exposure of hemocytes to low $\mathrm{pH}$, the total time between beginning of sonication of dinoflagellate suspensions and the end of incubations was minimized and never exceeded $4 \mathrm{~h}$. A PST stability test, performed using dinoflagellate extracts prepared in FSW and incubated for up to $5 \mathrm{~h}$, showed that initial total toxicity (in $\mu \mathrm{g}$ STXeq) was reduced by only $7.1 \%$ over this period. This reduction was not statistically significant (ANOVA, $P=0.715$ ). To ascertain the toxicity of $A$. tamarense used in these trials, duplicate or triplicate samples of both strains were pelletized by centrifugation ( $\sim 0.8$ to $1 \times 106$ cells per sample) and stored at $-80^{\circ} \mathrm{C}$ before being lyophilized and airshipped to IMB/NRC for toxin analysis. Samples were extracted in $0.03 \mathrm{M}$ acetic acid using the procedure described by Bricelj et al. (1990) and analyzed by high pressure liquid chromatography-fluorescence detection following the methods of Oshima (1995). Individual toxins were calibrated with toxin standards obtained from the Certified Reference Materials Program (CRMP) at IMB/NRC. Toxicities were converted to saxitoxin equivalents (STXeq) using a conversion factor of $0.23 \mu \mathrm{g}$ STXeq mouse units (MU) ${ }^{-1}$ and potency values of individual toxins (MU $\mu \mathrm{mole}^{-1}$ ) determined by Oshima (1995).

Clam collection and maintenance

Mya arenaria, averaging $63 \pm 1.1$ (sem) $\mathrm{mm}$ in shell length (SL) were collected from Aber Benoit, northern Brittany, and R. philippinarum (mean SL $=36 \pm 2.8 \mathrm{~mm}$ ), from the Gulf of Morbihan and the Bay of Brest, western Brittany, France, in December 2006 and January 2007. Collection sites for R. philippinarum were selected for their low Alexandrium spp. concentrations during red tides, in order to increase the probability of obtaining clams that had not been subjected to natural selection for resistance to PSTs. The Gulf of Morbihan and Bay of Brest are characterized by relatively low densities of A. minutum during red tides (typically $<600$ and $<2,100$ cells $\mathrm{L}^{-1}$ respectively (http:// www.ifremer.fr/envlit/surveillance/rephy.htm). Mya arenaria occurs sparsely in Brittany; thus the collection site for this species was selected because it had a high density of clams. Extremely high Alexandrium spp. densities, up to 13.8 cells $\mu \mathrm{L}^{-1}$ in 2001 , have been known to occur in the Abers of northern Brittany (http://www.ifremer.fr/envlit/ surveillance/rephy.htm). After collection, the clams were maintained at IUEM in sand-filled trays in a flow-through system receiving water from the Bay of Brest. Water temperature was maintained at $14 \pm 1^{\circ} \mathrm{C}$; salinity was $\sim 35 \%$. The clams were fed cultured algae (Isochrysis galbana and Pavlova spp.) delivered continuously from a reservoir via a peristaltic pump.

Ruditapes philippinarum in the Gulf of Morbihan can be affected by Brown Ring Disease (BRD) caused by a marine bacterium, Vibrio tapetis (Paillard 2004). Diseased individuals are often found at the sediment surface. For this study, only those clams that were burrowed below the surface were collected to avoid potentially confounding effects of BRD. The BRD prevalence in clams used in this study was very low (13\%), and most affected individuals were in recovery stages (V. M. Bricelj et al., unpublished data). 
Hemocyte collection and preparation

Hemolymph was collected from $M$. arenaria by inserting a 25 -gauge needle attached to a $1-\mathrm{mL}$ syringe directly between the valve margins into the posterior adductor muscle. Hemolymph was similarly collected from $R$. philippinarum except that the needle was inserted through the hinge ligament into the posterior adductor muscle (Oubella et al. 1993). In each case, $0.5 \mathrm{~mL}$ of hemolymph was drawn into $0.5 \mathrm{~mL}$ ice-cold $0.22-\mu \mathrm{m}$ FSW in the syringe. Immediate dilution in cold FSW inhibited hemocyte clumping. For most experiments, $0.5 \mathrm{~mL}$ hemolymph per individual was sufficient. When a greater volume was required, it was obtained in two separate withdrawals. A small drop of each sample was immediately examined microscopically to verify that it contained hemocytes and was free of debris. Once verified, the needle was removed from the syringe and the sample was gently expelled into a labeled tube and held on ice until assayed. Hemocyte concentrations were obtained using the flow cytometer, except for two experiments in which they were determined microscopically using a Malassez counting chamber. The two methods were correlated $(P<0.0001 ; r 2=0.76)$, but the microscope counts were about $40 \%$ higher than those obtained by the flow cytometer. Hemocyte concentrations were not standardized within or between experiments to avoid the need for centrifugation and resuspension, which enhances the formation of aggregates and makes subsequent counting difficult. The validity of this method is shown by the fact that the results were unrelated to the number of hemocytes in the wells (see Results). Pooled samples were between 0.8 and $5 \times 106$ hemocytes $\mathrm{mL}^{-1}$; individual hemocyte densities ranged from $1.9 \times 105$ to $1.2 \times 107$ cells $\mathrm{mL}^{-1}$ (Table 1).

Hemocyte assays

The adherence assay measures the proportion of hemocytes that detach from the surface of experimental chambers after incubation with potential toxins as previously described for clams by Choquet et al. (2003). The assay was conducted in 24-well plates. When pooled hemocyte samples were used, 6-12 replicate wells were established for each treatment; when individual bivalves were assayed, a single well per individual was employed for each treatment and the control. In order of application, the following were placed in each well: 100 $\mu \mathrm{L}$ FSW, $200 \mu \mathrm{L}$ hemolymph (diluted 1:1 in FSW), and $200 \mu \mathrm{L}$ of algal extract. (Preliminary experiments determined that there was no consistent, statistically significant effect of the order of application of hemocytes and extract.) Control wells contained FSW rather than algal extract. The plates were covered and incubated at $15-16^{\circ} \mathrm{C}$ for $3 \mathrm{~h}$. At the end of the incubation period, $500 \mu \mathrm{L}$ of $6 \%$ formalin was added to each well to stop activity and fix the cells. The nonadherent cells in each well were then gently pipetted off from one edge of the well after the plate had been tipped so that the supernatant was concentrated to that side. The reproducibility of the method is shown by the small variability among the wells established for the pooled samples (see Results). The nonadherent cells were placed in a flow cytometry (FCM) tube $(12$ x $75 \mathrm{~mm}$, BD FalconTM) and the fluorescent dye SYBR green I (Molecular Probes, Eugene, Oregon, USA, 1/10 of the DMSO commercial solution in distilled water) which intercalates into double stranded DNA, was added to each tube in a ratio of 1 $\mu \mathrm{L}$ to each $100 \mu \mathrm{L}$ of solution. The tubes were incubated at room temperature in the dark for approximately 1.5 h. Nonadherent cells were counted using a flow cytometer (FACSCalibur, BD Biosciences, San Jose, CA, USA) equipped with a $488 \mathrm{~nm}$ argon laser. Visualisation of SYBR Green stained cells on a side scatter (SSC, cell complexity) versus green fluorescence (FL1 - 530/30 band pass filter) cytogram (Fig. 1) allowed counting of the number of nonadherent cells passing in a 60-s subsample. The concentration of nonadherent cells was calculated using the count time and flow rate of the cytometer, as estimated by the method of Marie et al. (1999) and their percentage was based on the total hemocyte density in the sample (Table 1). Phagocytosis was estimated as the proportion of hemocytes that were associated with at least three 2- $\mu \mathrm{m}$ fluorescent beads (Fluoresbrite microspheres $2.5 \%$ solids-latex yellow-green $2.0 \mu \mathrm{m}$, Polysciences 18338). The threshold of three beads was established by comparing fluorescence of hemocytes incubated with and without cytocholasin B, which prevents phagocytosis by inhibiting actin polymerization, but not attachment of beads to hemocyte surfaces (Hégaret et al. 2003). There was no statistical difference in the first two fluorescence peaks, representing one and two beads, between the treated and untreated hemocytes. Thus, ingestion of beads was differentiated from simple attachment by excluding the first two peaks. Phagocytosis was assayed in FCM tubes. In order of application, the following were placed in each tube: $100 \mu \mathrm{L}$ FSW, $50 \mu \mathrm{L}$ 2- $\mu \mathrm{m}$ fluorescent beads, $200 \mu \mathrm{L}$ of algal extract, and $200 \mu \mathrm{L}$ hemolymph (diluted 1:1 in FSW). The contents were gently mixed and incubated at $15-16^{\circ} \mathrm{C}$ for $2 \mathrm{~h}$. At the end of the incubation period, the tubes were placed on ice to stop phagocytic activity. The samples were analyzed immediately. Hemocytes containing fluorescent beads were determined by the level of fluorescence of the FL1 detector. The number of cells containing three beads or more was evaluated (Fig. 2) and percentages computed as above.

Characterization of individual resistance of bivalves to PSTs

Individual Mya arenaria used in these trials were airshipped frozen on dry ice to the University of Maine, USA, for genotype analysis, i.e., resistance to PSTs as determined from the gene sequence of Domain II of the sodium channel pore region following previously described methods (Connell et al. 2007). A molecular probe for PST 
resistance is not available for $R$. philippinarum at present; however, individual sensitivity to PSTs of Manila clams from this source population (but not from the individuals used in hemocyte trials) was determined from parallel experiments based on their burrowing incapacitation after exposure to strain PR18b following the methods of Bricelj et al. (2004a). Results of these experiments indicated that $\sim 51 \%$ of this R. philippinarum population was sensitive to PSTs (V. M. Bricelj et al., unpublished data). Therefore it is expected that both PST resistant and sensitive clams were represented in the test population used in the present study.

\section{Experiments}

Experiment 1: To examine the effect of the PST-producing dinoflagellate strain (PR18b), an extract from this isolate was compared with that from the nonPST-producing strain (CCMP115). Extracts from both strains were tested on pooled hemocytes from 7 M. arenaria.

Experiment 2: Because the adherence assay was originally developed to estimate the toxicity of bacteria, especially strains of the Brown Ring Disease agent, Vibrio tapetis, on hemocytes of $R$. philippinarum (Choquet et al. 2003), $V$. tapetis was used as a positive control in an experiment assessing the effects of $A$. tamarense on hemocytes of both $R$. philippinarum and M. arenaria. Bacteria were prepared according to Choquet et al. (2003) and applied at the ratio of 25 bacteria per hemocyte. Hemocytes were pooled separately from 3 R. philippinarum and from $7 \mathrm{M}$. arenaria. Note that in this experiment only, the hemolymph from $R$. philippinarum was not diluted in the syringe.

Experiment 3: To examine the effect of reducing the standard dosage of extract on adherence, a test comparing extracts from $5 \times 105$ and $2.5 \times 105$ cells $\mathrm{mL}^{-1}$, was conducted on hemocytes pooled from 7 R. philippinarum.

Experiments 4 and 5: To investigate individual variability in the response to algal extracts, phagocytosis and adherence were measured in 12 individuals each of $M$. arenaria and $R$. philippinarum. Both phagocytosis and adherence assays were performed on the same clams: $R$. philippinarum on the same day and M. arenaria 4 days apart.

Statistical analysis

The effect of algal treatment was analyzed by one-way ANOVA. The fractional values for phagocytosis and adherence were arcsin-transformed, and hemocyte concentrations were log10-transformed, before analysis. Pairwise differences were investigated with a Scheffé's post-hoc test. Data were backtransformed for presentation in figures. Interindividual comparisons were made after dividing treatment by control values for the same individual to provide phagocytic- and nonadherent-cell ratios (Choquet et al. 2003). Relationships between treatment results for individual clams were determined using a Kendall rank correlation. Differences were considered statistically significant at $\alpha=0.05$.

\section{Results}

Dinoflagellate toxicity

The mean toxicity of the PST-producing A. tamarense strain PR18b used in these trials ranged from 66 to $85 \mathrm{pg}$

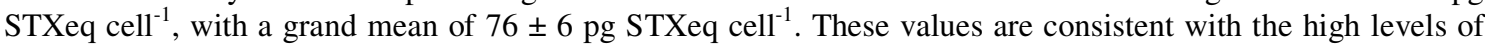
toxicity determined in previous studies using this strain (e.g., Bricelj et al., 2005). The toxin molar composition of strain PR18b was dominated by N-sulfocarbamoyl toxins C1+2 (averaging 54.4\%), followed by STX (26.1\%) and NEO (15.8\%), with smaller amounts of the gonyautoxins GTX2+3 (2.2\%) and B1 (1.3\%). This toxin profile is a relatively constant feature of this particular isolate although it can vary somewhat with culture conditions. Toxin analysis also confirmed that strain CCMP115 had undetectable PST levels. Spirolides, macrocyclic imine toxins produced by A. ostenfeldii (Cembella et al. 1999), were not detected in liquid chromatography- mass spectrometry/mass spectrometry analysis of lipophylic extracts of either strain (M. Quilliam, Analytical Laboratory, IMB/NRC, personal communication). Based on a mean cell toxicity of $76 \mathrm{pg} \mathrm{STXeq}$ cell $^{-1}$, a total volume of $500 \mu \mathrm{L}$ per well and a dinoflagellate concentration of 500 cells $\mu \mathrm{L}^{-1}$ for extract preparation, it can be estimated that hemocytes in the PST treatments were exposed to a concentration equivalent to $50.8 \mu \mathrm{M}$ STX during assays.

Hemocyte assays

Experiment 1: Comparison of PST- and nonPST-producing A. tamarense on adherence (Fig. 3). The proportion of $M$. arenaria hemocytes that were nonadherent (11\%) after incubation with the nonPST-producing strain (CMP115) was 5 times greater than the proportion detached by the PST-producing strain (PR18b). There was no statistically significant difference between the PST strain (3\%) and the controls (2\%). 
Experiment 2: Comparison of A. tamarense and V. tapetis on adherence (Fig. 4). The nonPST-producing strain again caused significantly greater detachment of $M$. arenaria hemocytes $(21 \%)$ than did the PST-producing strain (10\%). Detachment caused by $V$. tapetis (used as a positive control) was $12 \%$ for $M$. arenaria, about the same as resulted from the PST treatment, whereas nearly $60 \%$ of the $R$. philippinarum hemocytes were detached by the bacterium. Less than $2 \%$ of control hemocytes of both clam species were nonadherent.

Experiment 3: Dose effect of A. tamarense on adherence (Fig. 5). A clear dose effect was demonstrated for the nonPSTproducing strain: the standard dose extracted from a concentration of 5 to $10^{5}$ cells $\mathrm{mL}^{-1}$ resulted in detachment of $10 \%$ of $R$. philippinarum hemocytes. Half that dose caused detachment of $5 \%$ of the hemocytes. In contrast, there was no difference in the proportion of nonadherent hemocytes incubated in equivalent dosages of the PST-producing strain (3-4\%). Only $1 \%$ of control hemocytes became detached.

Experiment 4: Effect of $A$. tamarense on adherence and phagocytosis of individual Mya arenaria. The mean detachment after incubation with the nonPSTproducing strain for the 12 individuals tested was $20 \%$ (Fig. 6a). Fewer than $2 \%$ of the hemocytes were nonadherent in the wells containing the PST extract and FSW. The mean percentage of phagocytic hemocytes in the PST and control groups (30 and 28\%, respectively) was three times that of the nonPST group (10\%) (Fig. 6b). The ratio of individual nonadherent to control values in the nonPST treatment ranged from 6 to 112 (Fig. 7a). All were much higher than the ratios for the PST-treated hemocytes, which ranged from 1 to 5. Only one individual (\#11), which had the highest ratios in both PST and nonPST treatments, fell outside the mean +2 standard deviation (SD) boundary or $95 \%$ confidence interval, and did so in both treatments. The phagocytic cell ratios for the PST-treated hemocytes ranged from 0.6 to 1.9 , and, for each individual, they were higher than the same values for the nonPST treatment, which ranged from 0.1 to 0.8 (Fig. 7b). No value was outside the 2 SD boundary, although the four individuals in the nonPST group with the highest ratios (\#s 5, 7, 10 and 12) also had among the highest ratios in the PST treatments. Individual nonadherent cell ratios for the PST exposure were significantly and positively correlated with values for the nonPST treatment (Kendall rank correlation, $P=0.014$ ), but not for the phagocytic cell ratios. The percentage of nonadherent or phagocytic hemocytes in the nonPST treatments was independent of the hemocyte concentrations in individual wells as determined by a non-significant correlation between these two parameters $\left(P=0.087, r^{2}=\right.$ 0.265 and $P=0.465, r^{2}=0.055$, respectively).

Experiment 5: Effect of A. tamarense on adherence and phagocytosis of individual Ruditapes philippinarum. An average $16 \%$ of hemocytes was nonadherent after incubation with the nonPST-producing strain, whereas only $4 \%$ of cells in the PST and control treatments were nonadherent (Fig. 8a). The mean percentage of phagocytic hemocytes in the PST and control groups (22\%) was more than four times that of the nonPST group (5\%) (Fig. $8 b$ ). Individual nonadherent values for the ratio of nonPSTtreated to control cells ranged from 0.6 to 9.2 ; the range for the PST-treated cells was 0.1-3.1 (Fig. 9a). All individual values fell within the 2 SD boundary, but the nonPST ratio was not greater than the PST ratio for all individuals. One (\#11) had a higher ratio for the PST treatment, and two (\#s 10 and 12) had similar ratios. Numbers 10 and 11 had the two lowest nonPST ratios, which were due to low treatment values, not high control values. Phagocytic cell ratios for the nonPST treated cells ranged from 0.1 to 1.0 and, for each individual, the nonPST value was higher than the PST value, which ranged from 0.5 to 2.3 (Fig. 9b). The phagocytic cell ratio of one individual in the nonPST treatment (\#9) was considerably higher than that of all other 11 clams. This individual also had the highest value in the PST treatment and both were above the 2 SD boundary. A Kendall Rank Correlation analysis showed no significant relationship in either assay among individuals treated with the PST and the nonPST-producing strains. The percentage of nonadherent or phagocytic hemocytes in the nonPST treatments was independent of the hemocyte concentrations in individual wells as determined by a non-significant correlation between these two parameters $\left(P=0.731, r^{2}=0.014\right.$ and $P=0.474, r^{2}=0.052$, respectively $)$.

Mya arenaria genotyping

Twenty-five $M$. arenaria were genotyped. Of these, 23 were of the genotype sensitive to PSTs. The remaining two were resistant heterozygotes, which appear to show intermediate resistance between homozygous sensitive and homozygous resistant (Connell et al. 2007). One each of the heterozygous resistant individuals was included in the pooled-hemocyte Experiments 1 and 2. Nine of the individuals tested in Experiment 4 were of the sensitive genotype (numbers 4, 7 and 11 could not be genotyped).

\section{Discussion}

The results of the in vitro experiments were unexpected. The extract from the PST-producing A. tamarense strain (PR18b) had almost no measurable effect on hemocytes of either Mya arenaria or R. philippinarum. This was despite the fact that the genotypes of $M$. arenaria included $92 \%$ of the PST-sensitive type, and the rest were intermediate between sensitive and resistant homozygote genotypes. Results of a parallel experiment that used 
burrowing incapacitation following $16 \mathrm{~h}$-exposure to strain PR18b as a measure of resistance to PSTs indicated that $\sim 51 \%$ of the $R$. philippinarum from the same source population were sensitive (i.e., non-burrowers) (V.M. Bricelj et al., unpublished results); thus sensitive Manila clams are expected to be well represented in our in vitro trials. Moreover, isolate PR18b is characterized by high PST levels relative to other PST-producing strains found in Canada and the northeastern United States (Cembella et al. 1988; Anderson et al. 1994). In contrast, extract from the nonPST-producing strain CCMP115 had a consistent negative effect, resulting in significantly greater detachment of hemocytes and a significantly lower fraction of phagocytic hemocytes compared to the PSTproducing strain and the controls. Previous tests of the effects of harmful algae on bivalve hemocytes have all employed intact algal cells, with toxicities lower than the PR18b strain that we used, rather than extracts. Nevertheless, our findings are consistent with an in vivo study that found no effects on phagocytosis (Hégaret et al. 2007) by hemocytes of oysters, Crassostrea gigas and $C$. virginica, exposed to a suspension of PSTproducing A. fundyense (strain BF2) and A. catanella (strain ATTL01), respectively, for up to seven days. In an in vitro study (Hégaret et al. 2008) also found no measurable effects of intact A. fundyense on phagocytosis by hemocytes of the hard clam, Mercenaria mercenaria. Further, Hégaret et al. (2007) found few effects on other hemocyte parameters such as viability, the production of reactive oxygen species (ROS), and total and differential counts despite the fact that $C$. virginica experienced adductor paralysis and $C$. gigas accumulated measurable, but relatively low toxin levels $\left(\sim 150 \mu \mathrm{g} \mathrm{STXeq} 100 \mathrm{~g}^{-1}\right)$ by feeding on strain ATTL01, which attains relatively low toxicities ranging from 0.04 (Lilly et al. 2002) to 15 pg STXeq cell ${ }^{-1}$ (Séchet et al. 2004). Hégaret et al. (2007) did find a significant positive relationship between toxin accumulation and the percentage of dead hemocytes, but only at the higher experimental temperature (18 vs. $\left.12^{\circ} \mathrm{C}\right)$, and Hégaret et al. (2008) reported lower adhesion of $M$. mercenaria hemocytes exposed in vitro to whole A. fundyense. Jones et al. (1995) reported transient increases in hemocyte counts and "relative phagocytic activity", measured by chemiluminescence, in $C$. gigas exposed in vivo to the domoic acid-producing Pseudonitzschia pungens f. multiseries. However, this study included no untreated control group; therefore, the true effect of the exposure cannot be determined. In another series of in vivo laboratory and field experiments, Hégaret and Wikfors (2005a, b) measured a suite of characteristics and functions of hemocytes from $C$. virginica and the scallop, Argopecten irradians, experimentally or naturally exposed to the nonPST-producing, but toxic, dinoflagellate Prorocentrum minimum. Most trials showed an increase in total hemocyte concentrations compared to controls. Consistent increases or decreases in other parameters, such as hemocyte viability, phagocytosis, aggregation and respiratory burst were much less evident, perhaps because of differences in the control diets in the different experiments (unfed, natural phytoplankton, and pre- $P$. minimum bloom samples). The authors interpreted their results as showing an effect of algal toxins on the immune status of the oysters and scallops; however, hemocytes function in nutrition as well as in defense (Cheng 1981; Fisher 1986). Thus hemocytes from bivalves offered different diets may be responding to the nutritional quality and quantity of those diets (Delaporte et al. 2003; Hégaret et al. 2004), not necessarily to the presence or absence of toxins. Failure to find an effect of concentrated, highly toxic PST on two bivalve hemocyte parameters, as shown in the present study, is perhaps not surprising because the mechanism of action of these compounds is to block the sodium channels of excitable nerve and muscle cells (Catterall 1992), thus causing paralysis. In fact, all of the bivalves mentioned above display whole-animal responses when exposed to PST-producing Alexandrium spp., ranging from paralysis and mortality in $M$. arenaria and $R$. philippinarum (Bricelj et al. 2005, unpublished data), to reduced clearance in $C$. gigas (Bardouil et al. 1993). Clearly, bivalve hemocytes are not sensitive to the sodium-channel blocking effected by PSTs (Hégaret et al. 2007), even when exposed to highly toxic dinoflagellate extracts (present study). Bivalve hemocytes were exposed in our bioassays to a concentration of $\sim 51 \mu \mathrm{M}$ STXeq. In comparison, PSTsensitive $M$. arenaria typically show $100 \%$ block of the nerve action potential at $\leq .33 \mu \mathrm{M}\left(\cdot \leq 10^{-5} \mathrm{~g} \mathrm{~mL}^{-1}\right)$ pure STX, whereas PST-resistant homozygous individuals require concentrations $>334 \mu \mathrm{M}\left(>10^{-4} \mathrm{~g} \mathrm{~mL}^{-1}\right)$ STX to exhibit full blocking of the action potential (Bricelj et al. 2005; Connell et al. 2007). Thus the PST concentration used in the present study was sufficient to cause paralysis of sensitive clams, yet had no detectable effect on adherence and phagocytosis of circulating hemocytes. The significant, negative effects of the nonPST-producing A. tamarense strain CCMP115 on both phagocytosis and adherence of hemocytes from the two bivalve species indicated that a bioactive compound other than PST was present in the algal extract. There was no effect on the burrowing capacity of $M$. arenaria exposed to this strain for $24 \mathrm{~h}$ (Bricelj et al. 2005), reinforcing the conclusion that the compound(s) that negatively affected hemocytes is distinct from the paralysis-causing toxin produced by the PST strain. Because harmful algal products are often classified according to their target organisms, considerable overlap of categories exists in the literature. For instance, several investigators have found that the known toxinproducing dinoflagellates, Alexandrium spp. and Prorocentrum lima also have allelopathic effects (Arzul et al. 1999; Sugg and VanDolah 1999; Tillmann and John 2002). Some studies, however, report clear toxinindependent allelopathic effects. Tillmann and John (2002) measured loss of motility and cell lysis in two heterotrophic dinoflagellates exposed to 16 strains of Alexandrium spp. (including CCMP115), only 5 of which produced detectable levels of PSTs. Although loss of motility in the target species, Oxyrrhis marina, was directly related to the PST content in these 5 isolates (range $=\sim 0$ to 100\%), it also occurred over the same range in the 11 
species that did not produce PSTs. Within the latter, strain CCMP115 was among the most noxious, causing motility loss in $80 \%$ of $O$. marina. Other investigators have similarly found allelopathic effects that are independent of brevetoxin (Kubanek et al. 2005) and okadaic acid production (Sugg and VanDolah 1999). Thus, results of our study support the findings of Tillmann and John (2002) regarding the production of a nonPST deleterious compound by this strain, but using a very different target organism. This finding is important because CCMP115 is commonly used as a control dinoflagellate in PST studies. The loss of normal shape described for some allelopathic effects is comparable to the rounding that precedes detachment of hemocytes in the adherence assay (Choquet et al. 2003). Further, the toxins produced by the dinoflagellate Karlodinium micrum that make cell membranes permeable to ions and small molecules, resulting in osmotic death, have been attributed a role in fish kills (Deeds et al. 2002). Accordingly, the compound(s) that affected hemocytes in our study may be part of the same general class of compounds that affect other algae and/or cause pathological changes in fish gills. The effects of the PST- and nonPST-producing extracts were clearly different in the experiments in which pooled hemocytes were used, in the means of individuals measured in Experiments 4 and 5, and in nearly all of the individual measurements; however, a few individuals did not show this "average" differentiation. Some clams showing the greatest response to the nonPST treatment also showed the greatest response to the PST treatment, suggesting that the effects of the two might be not entirely independent. Also, a few individual R. philippinarum did not respond with greater hemocyte detachment after nonPST treatment than after PST incubation. These observations show the usefulness of examining individual, as well as pooled or mean, data; however, they are based on a relatively small sample size, and without individual replication, and thus remain preliminary. Hemocytes would first encounter toxic algae in the bivalve pallial cavity, where the former are plentiful (Paillard et al. 1996; Allam and Paillard 1998); however, they probably would be exposed only to intact algal cells in this compartment. They would more likely be exposed to the bioactive compound only after the algae are ingested and at least partially digested in the gut (Owen 1966). Although the presence of intact Alexandrium spp. cells in bivalve feces is well documented (e.g., Bricelj and Shumway 1998; Labir and Gentien 1999), absorption efficiencies of 62- 88\% have been reported for bivalves feeding on Alexandrium spp. (Bricelj et al. 1990; Li et al. 2002), demonstrating effective cell breakdown and digestion during gut passage. Further, because the culture medium was removed by sieving and washing immediately prior to extract preparation in the present study, the deleterious effects of strain CCMP115 can be attributed to an intracellular bioactive compound, which may or may not be released into the surrounding medium. Hemocytes readily pass through the bivalve gut epithelium from the circulatory system into the lumen of the digestive tract (George 1952), where they can phagocytose partially digested algae or pinocytose dissolved substances (Feng 1965; Owen 1966) and transport them back across the gut epithelium and into circulation (Alvarez et al. 1992). They are also capable of intracellular digestion (Cheng and Cali 1974). Thus, circulating hemocytes would have multiple opportunities for exposure to the bioactive compound(s) produced by the nonPST-producing A. tamarense. The extract required to register a significant in vitro response by hemocytes in our assay was obtained from a relatively high concentration of $A$. tamarense, equivalent to 2 to $10^{5}$ cells $\mathrm{mL}^{-1}$ in each well plate. This is two orders of magnitude higher than that used by Tillmann and John (2002) who elicited an adverse effect on a heterotrophic dinoflagellate with an Alexandrium spp. concentration of 3.9 to $10^{3}$ cells $\mathrm{mL}^{-1}$ in each well plate for both whole cell and cell-free filtrate incubations. However, visceral tissues of bivalves can accumulate very high levels of water-soluble toxins and could thus potentially also accumulate high concentrations of the nonPST bioactive compound released by strain CCMP115. Additionally, we have shown that the PST concentration from strain PR18b to which hemocytes were exposed in our study was in the range that results in full nerve block of $M$. arenaria (sensitive genotype). Thus the exposure concentration of PSTs used in this study is expected to have been sufficiently high to elicit a response if hemocytes were susceptible to these toxins. Our results indicate that a rapid, hemocyte-based in vitro assay for the whole-organism effects of PSTs on bivalves, as initially proposed, would not be useful for the important PST-producer, A. tamarense. However our results with strain CCMP115 indicate that an in vitro assay may prove useful to screen for toxicity and to investigate the mechanism of action of other harmful algae that produce as yet unknown deleterious compounds. It would be especially useful if in vitro hemocyte effects were found to correlate with whole animal functions such as feeding and growth, which are known to be inhibited by toxic algae (Gainey and Shumway 1991; Bricelj et al. 2004b), or resistance to disease. In addition to being rapid, such an assay would have the added benefit of requiring relatively small amounts of algal biomass compared to in vivo trials and thus have potential application for bioassay guided fractionation studies required for the chemical identification of other unknown toxin compounds. Finally, it would be of interest to extend the results of this study by screening extracts from other Alexandrium spp. (both PSTand nonPST-producing) to determine their effects on bivalve hemocyte function and to chemically characterize the non- PST bioactive compound(s) involved.

Acknowledgments This study was conducted with support from the French Centre Nationale de la Recherche Scientifique (CNRS) to VMB and from the US NOAA-Ecology and Oceanography (ECOHAB) Program (Grant \#NA06NOS4780247) and is ECOHAB publication no. 257. We are grateful to Annaïck Barbou, Marcel Koken, 
Alain Le Mercier, and Alain Marhic at IUEM for their generous help throughout the project; Stephane Pouvreau (IFREMER, Station d'Argenton) and Michel Le Duff (IUEM) for their help in locating, and sampling, the Aber Benoit $M$. arenaria population, respectively; and the "Host- Pathogens Interactions" group at IUEM who helped in digging clams. We thank Laurie Connell, School of Marine Sciences, University of Maine at Orono for gene sequencing of Mya arenaria specimens used in this study, Michael Quilliam, IMB/NRC, for spirolide analysis of the two A. tamarense strains used, and Scott MacQuarrie, IMB/NRC, for his technical assistance. Contribution no. 1073 of IUEM and publication no. 2008-4772 from IMB/NRC. 


\section{References}

Allam B, Paillard C (1998) Defense factors in clam extrapallial fluids. Dis Aquat Org 33:123-128

Allam B, Ashton-Alcox KA, Ford SE (2002) Flow cytometric measurement of hemocyte viability and phagocytic activity in the clam Ruditapes philippinarum. J Shellfish Res 21:13-19

Alvarez MR, Friedl FE, Johnson JS, Hinsch GW (1989) Factors affecting in vitro phagocytosis in oyster hemocytes. J Invert Pathol 54:233-241

Alvarez MR, Friedl FE, Hudson CM, O'Neill RL (1992) Uptake and tissue distribution of abiotic particles from the alimentary tract of the American Oyster: a simulation of intracellular parasitism. J Invert Pathol 59:290-294

Anderson DM, Kulis DM, Doucette GJ, Gallagher JC, Balech E (1994) Biogeography of toxic dinoflagellates in the genus Alexandrium from the northeastern United States and Canada. Mar Biol 120:467-478

Arzul G, Gentien P (2006) Allelopathic interactions among marine microalgae. In: Subba Rao DV (ed) Algal cultures, analogues of blooms and applications. Science Publishers, Enfield, pp 131-161

Arzul G, Seguel M, Guzman L, Erard-Le Denn E (1999) Comparison of allelopathic properties in three toxic Alexandrium species. J Exp Mar Biol Ecol 232:285-295

Bardouil M, Bohec M, Cormerais M, Bougrier S, Lassus P (1993) Experimental study of the effects of a toxic microalgal diet on feeding of the oyster Crassostrea gigas Thunberg. J Shellfish Res 12:417-422

Behrends B, Hertweck G, Liebezeit G, Goodfriend G (2005) Earliest Holocene occurrence of the soft-shell clam, Mya arenaria, in the Grefswalder Bodden, Southern Baltic. Mar Geol 216:79-82

Bougrier S, Lassus P, BeliaeV B, Bardouil M, Masselin P, Truquet P, Matignon F, Mornet F, Le Baut C (2001) Feeding behavior of individuals and groups of king scallops (Pecten maximus) contaminated experimentally with PSP toxins and detoxified. In: Hallegraef G, Blackburn SI, Bolch CJ, Lewis RJ (eds) Harmful algal bloom. Intergovernmental Oceanographic Commission, UNESCO, France, pp 407-410

Bricelj VM, Shumway SE (1998) Paralytic shellfish toxins in bivalve molluscs. Occurrence, transfer kinetics and biotransformation. Rev Fish Sci 6:315-383

Bricelj VM, Lee JH, Cembella AD, Anderson DM (1990) Uptake kinetics of paralytic shellfish toxins from the dinoflagellate Alexandrium fundyense in the mussel Mytilus edulis. Mar Ecol Prog Ser 63:177-188

Bricelj VM, MacQuarrie SP, Twarog BM, Trainer V (2004a) Characterization of sensitivity to PSP toxins in North American populations of the softshell clam Mya arenaria. In: Steidinger KA, Landsberg JH, Tomas CR, Vargo GA (eds) Harmful algae 2002. Florida Fish and Wildlife Conservation Commission, Florida Institute of Oceanography and Intergovernmental Oceanographic Commission of UNESCO, pp 172-174

Bricelj VM, MacQuarrie SP, Smolowitz R (2004b) Concentrationdependent effects of toxic and non-toxic isolates of the brown tide alga Aureococcus anophagefferens on growth of juvenile bivalves. Mar Ecol Prog Ser 282:101-114

Bricelj VM, Connell L, Konoki K, MacQuarrie SP, Scheuer T, Catterall WA, Trainer VL (2005) Sodium channel mutation leading to saxitoxin resistance in clams increases risk of PSP. Nature 434:763-767

Catterall WA (1992) Cellular and molecular biology of voltage-gated sodium channels. Physiol Rev 72: S15-S48

Cembella AD, Therriault J-C, Béland P (1988) Toxicity of cultured isolates and natural populations of Protogonyaulax tamarensis from the St. Lawrence estuary. J Shellfish Res 7:611-621

Cembella AD, Lewis NI, Quilliam MA (1999) Spirolide composition of micro-extracted pooled cells isolated from natural plankton assemblages and from cultures of the dinoflagellate Alexandrium ostenfeldii. Natural Toxins 7:197-206

Cheng TC (1981) Bivalves. In: Ratcliffe NA, Rowley AF (eds) Invertebrate blood cells. Academic Press, London, pp 233-299

Cheng TC, Cali A (1974) An electron microscope study of the fate of bacteria phagocytosed by granulocytes of Crassostrea virginica. Contemp. Top Immunobiol 4:25-35

Choquet G, Soudant P, Lambert C, Nicolas JL, Paillard C (2003) Reduction of adhesion properties of Ruditapes philippinarum hemocytes exposed to Vibrio tapetis. Dis Aquat Org 57:109-116

Connell LB, MacQuarrie SP, Twarog BM, Iszard M, Bricelj VM (2007) Population differences in nerve resistance to paralytic shellfish toxins in softshell clam, Mya arenaria, associated with sodium channel mutations. Mar Biol 150:1227-1236

Cusack CK, Bates SS, Quilliam MA, Patching JW, Raine R (2002) Confirmation of domoic acid production by Pseudo-nitzschia australis (Bacillariophyceae) isolated from Irish waters. J Phycol 38:1106-1112

Deeds JR, Terlizzi DE, Adolf JE, Stoecker DK, Place AR (2002) Toxic activity from cultures of Karlodinium micrum (=Gyrodinium golathanum) (Dinophyceae) — a dinoflagellate associated with fish mortalities in estuarine aquaculture facility. Harmful Algae 1:169-189

Delaporte M, Soudant P, Moal J, Lambert C, Quere C, Miner P, Choquet G, Paillard C, Samain JF (2003) Effect of a mono-specific algal diet on immune functions in two bivalve species-Crassostrea gigas and Ruditapes philippinarum. J Exp Biol 206:3053-3064

Feng SY (1965) Pinocytosis of proteins by oyster leucocytes. Biol Bull 129:95-105

Fisher WS (1986) Structure and functions of oyster hemocytes. In: Brehélin M (eds) Immunity in Invertebrates. Springer, Berlin, pp 25-35

Flassch JP, Leborgne Y (1992) Introduction in Europe, from 1972 to 1980 of the Japanese Manila clam, Tapes philippinarum and the effects on the aquaculture production and natural settlements. ICES Mar Sci Symp Copenhagen 194:92-96 
Gainey LF, Shumway SE (1991) The physiological effect of Aureococcus anophagefferens ('brown tide') on the lateral cilia of bivalve mollusks. Biol Bull 181:298-306

George WC (1952) The digestion and absorption of fat in lamellibranchs. Biol Bull 102:118-127

Guillard RRL, Hargraves PE (1993) Stichochrysis immobilis is a diatom, not a chrysophyte. Phycologia 32:234-236

Hallegraef GM (1993) A review of harmful algal blooms and their apparent global increase. Phycologia 32:79-99

Hégaret H, Wikfors GH (2005a) Effects of natural and field-simulated blooms of the dinoflagellate Prorocentrum minimum upon hemocytes of eastern oysters, Crassostrea virginica, from two different populations. Harmful Algae 4:201-209

Hégaret H, Wikfors GH (2005b) Time-dependent changes in hemocytes of eastern oysters, Crassostrea virginica, and northern bay scallops, Argopecten irradians irradians, exposed to a cultured strain of Prorocentrum minimum. Harmful Algae 4:187199

Hégaret H, Wikfors GH, Soudant P (2003) Flow cytometric analysis of haemocytes from eastern oysters, Crassostrea virginica, subjected to a sudden temperature elevation II. Haemocyte functions: aggregation, viability, phagocytosis, and respiratory burst. J Exp Mar Biol Ecol 293:249-265

Hégaret H, Wikfors GH, Soudant P, Delaporte M, Alix JH, Smith BC, Dixon MS, Quere C, Le Coz JR, Paillard C, Moal J, Samain JF (2004) Immunological competence of eastern oysters, Crassostrea virginia, fed different microalgal diets and challenged with a temperature elevation. Aquaculture 234:541-560

Hégaret H, Wikfors GH, Soudant P, Lambert C, Shumway SE, Bérard JB, Lassus P (2007) Toxic dinoflagellates (Alexandrium fundyense and A. catenella) have minimal apparent effects on oyster hemocytes. Mar Biol 152:441-444

Hégaret H, Wikfors GH, Shumway SE (2008) In vitro interactions between several species of harmful algae and hemocytes of bivalve molluscs. In: Proceedings of the 2007 international harmful algae conference, Copenhagen, Denmark (in press)

Jones TO, Whyte JNC, Ginther NG, Townsend LD, Iwama GK (1995) Haemocyte changes in the Pacific oyster, Crassostrea gigas, caused by exposure to domoic acid in the diatom Pseudonitzschia pungens $f$. multiseries. Toxicon 33:347-353

Keller MD, Bellows WK, Guillard RL (1988) Microwave treatment for sterilization of phytoplankton culture media. J Exp Mar Biol Ecol 117:279-283

Kubanek J, Hicks MK, Naar J, Villareal TA (2005) Does the red tide dinoflagellate Karenia brevis use allelopathy to outcompete other phytoplankton? Limnol Oceanogr 50:883-895

Labir M, Gentien P (1999) Survival of toxic dinoflagellates after gut passage in the Pacific oyster Crassostrea gigas Thunberg. J Shell- fish Res 18:217-222

Li S-C, Wang W-X, Hsieh DPH (2002) Effects of toxic dinoflagellate Alexandrium tamarense on the energy budgets and growth of two marine bivalves. Mar Environ Res 53:145-160

Lilly EL, Kulis DM, Gentien P, Anderson DM (2002) Paralytic shell- fish poisoning toxins in France linked to a human-introduced strain of Alexandrium catenella from the western Pacific: evidence from DNA and toxin analysis. J Plankton Res 24:443452

Lundholm N, Hansen PJ, Kotaki Y (2005) Lack of allelopathic effects of the domoic acid-producing marine diatom Pseudo-nitzschia multiseries. Mar Ecol Prog Ser 288:21-33

Marie D, Partensky F, Vaulot D, Brussaard CPD (1999) Enumeration of phytoplankton, bacteria, and viruses in marine samples. In: Robinson JP, Darzynkiewicz Z, Dean PN, Orfao A, Rabinovitch P, Stewart C, Tanke HJ, Wheeless L (eds) Current protocols in cytometry. Wiley, New York, pp 11.11.11-11.11.15

Ordas MC, Novoa B, Figueras A (1999) Phagocytosis inhibition of clam and mussel haemocytes by Perkinsus atlanticus secretion products. Fish Shellfish Immunol 9:491-503

Oshima Y (1995) Post-column derivatization HPLC methods for paralytic shellfish poisons. In: Hallegraef GM, Anderson DM, Cembella AD (eds) Manual of harmful marine microalgae. International Oceanographic Commission Manuals and Guides, UNESCO, Paris, pp 81-94

Oubella R, Maes P, Paillard C, Auffret M (1993) Experimentally induced variation in hemocyte density for Ruditapes philippinarum and $R$. decussatus (Mollusca, Bivalvia). Dis Aquat Org 15:193-197

Owen G (1966) Digestion. In: Wilbur KM (ed) Physiology of Mollusca. Academic Press, New York, pp 53-96

Paillard C (2004) A short review of brown ring disease, a vibriosis affecting clams, Ruditapes philippinarum and Ruditapes decussatus. Aquat Liv Res 17:467-475

Paillard C, Ashton-Alcox K, Ford SE (1996) Changes in bacterial densities and hemocyte parameters in oysters affected by Juvenile Oyster Disease. Aquat Liv Res 9:145-158

Séchet V, Bérard JB, Bohec M, Bougaran G, Carré, Masselin P, Truquet P (2004) Continuous-flow and batch cultures of toxic Alexandrium catenella and A. minutum in stirred tank bioreactors. In: Steidinger KA, Landsberg JH, Tomas CR, Vargo GA (eds) Harmful Algae 2002. Florida Fish and Wildlife Conservation Commission, Florida Institute of Oceanography and Intergovernmental Oceanographic Commission of UNESCO, pp 399-401

Shumway SE (1990) A review of the effects of algal blooms on shell- fish and aquaculture. J World Aquacult Soc 21:65-104

Shumway SE, Cucci TL (1987) The effects of the toxic dinoflagellate Protogonyaulax tamarensis on the feeding and behavior of bivalve molluscs. Aquatic Toxicol 10:9-27

Soudant P, Paillard C, Choquet G, Lambert C, Reid HI, Marhic A, Donaghy L, Birkbeck TH (2004) Impact of season and rearing site on the physiological and immunological parameters of the Manila clam Venerupis (=Tapes, =Ruditapes) philippinarum. Aquaculture 229:401-418

Sugg LM, VanDolah FM (1999) No evidence for an allelopathic role of okadaic acid among ciguatera-associated dinoflagellates. J Phycol 35:93-103 
Tang YZ, Kong LS, Holmes MJ (2007) Dinoflagellate Alexandrium leei (Dinophyceae) from Singapore coastal waters produces a water-soluble ichthyotoxin. Mar Biol 150:541-549

Tillmann U, John U (2002) Toxic effects of Alexandrium spp. on heterotrophic dinoflagellates: an allelochemical defence mechanism independent of PSP-toxin content. Mar Ecol Prog Ser 230:47-58

Tillmann U, John U, Krock B, Cembella A (2007) Allelopathic effects of bioactive compounds produced by harmful algae. In: Proceedings of the 2007 international harmful algae conference, Copenhagen Twarog BM, Hidaka T, Yamaguchi H (1972) Resistance to tetrodotoxin and saxitoxin in nerves of bivalve mollusks. Toxicon 10:273-278 
Table 1 List of experiments showing bivalve species (Mya arenaria or Ruditapes phillipinarum) and hemocyte concentrations in experimental clams.

\begin{tabular}{|c|c|c|c|c|c|}
\hline \multirow[t]{2}{*}{ Experiment } & \multirow[t]{2}{*}{ Clam species } & \multirow{2}{*}{$\begin{array}{l}\text { Sample } \\
\text { type }\end{array}$} & \multicolumn{3}{|c|}{ Hemocyte densities $\left(\mathrm{mL}^{-1}\right)^{\mathrm{a}}$} \\
\hline & & & Mean & Minimum & Maximum \\
\hline 1 & M. arenaria & Pooled & $8.16 \times 10^{5}$ & - & - \\
\hline 2 & M. arenaria & Pooled & $1.46 \times 10^{6}$ & - & - \\
\hline 2 & R. philippinarum ${ }^{\mathrm{b}}$ & Pooled & $2.07 \times 10^{6}$ & - & - \\
\hline 3 & R. philippinarum ${ }^{\mathrm{c}}$ & Pooled & $9.20 \times 10^{5}$ & - & - \\
\hline 4 & M. arenaria & Individual & $4.96 \times 10^{6}$ & $2.30 \times 10^{6}$ & $1.17 \times 10^{7}$ \\
\hline 5 & R. philippinarum ${ }^{\mathrm{b}}$ & Individual & $8.76 \times 10^{5}$ & $1.93 \times 10^{5}$ & $2.7 \times 10^{6}$ \\
\hline
\end{tabular}

a Experiments 1 and 2 hemocyte counts by microscope; others by flow cytometer

$\mathrm{b}$ Gulf of Morbihan origin

c Bay of Brest origin 

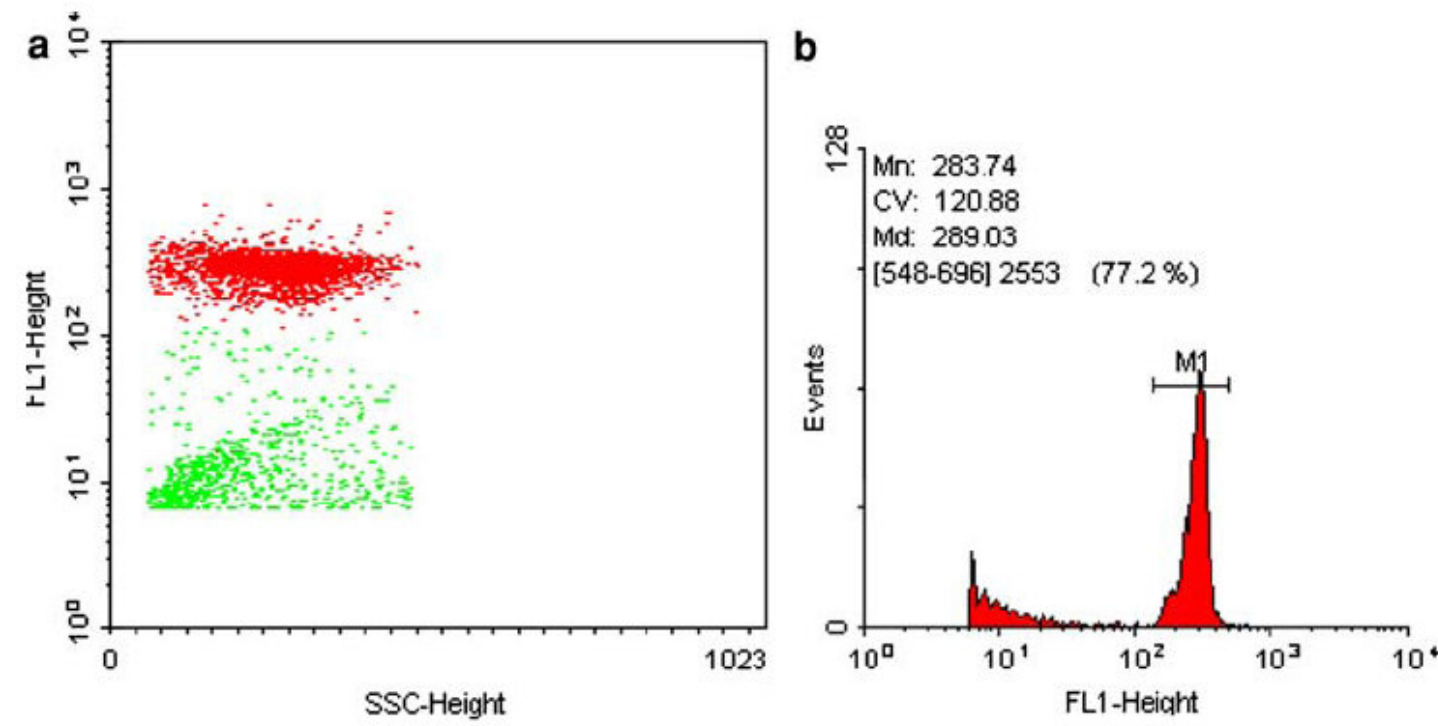

Fig. 1 Example of flow cytometer results for the adherence assay: a side scatter (SSC, cell complexity) versus green fluorescence (FL1) cytogram showing SYBR green-stained nonadherent hemocytes (red color) and non fluorescent debris (green color), b FL1 fluorescence histogram; $M 1$ number of events showing FL1 fluorescence corresponding to stained hemocytes (here M1 = 2553)
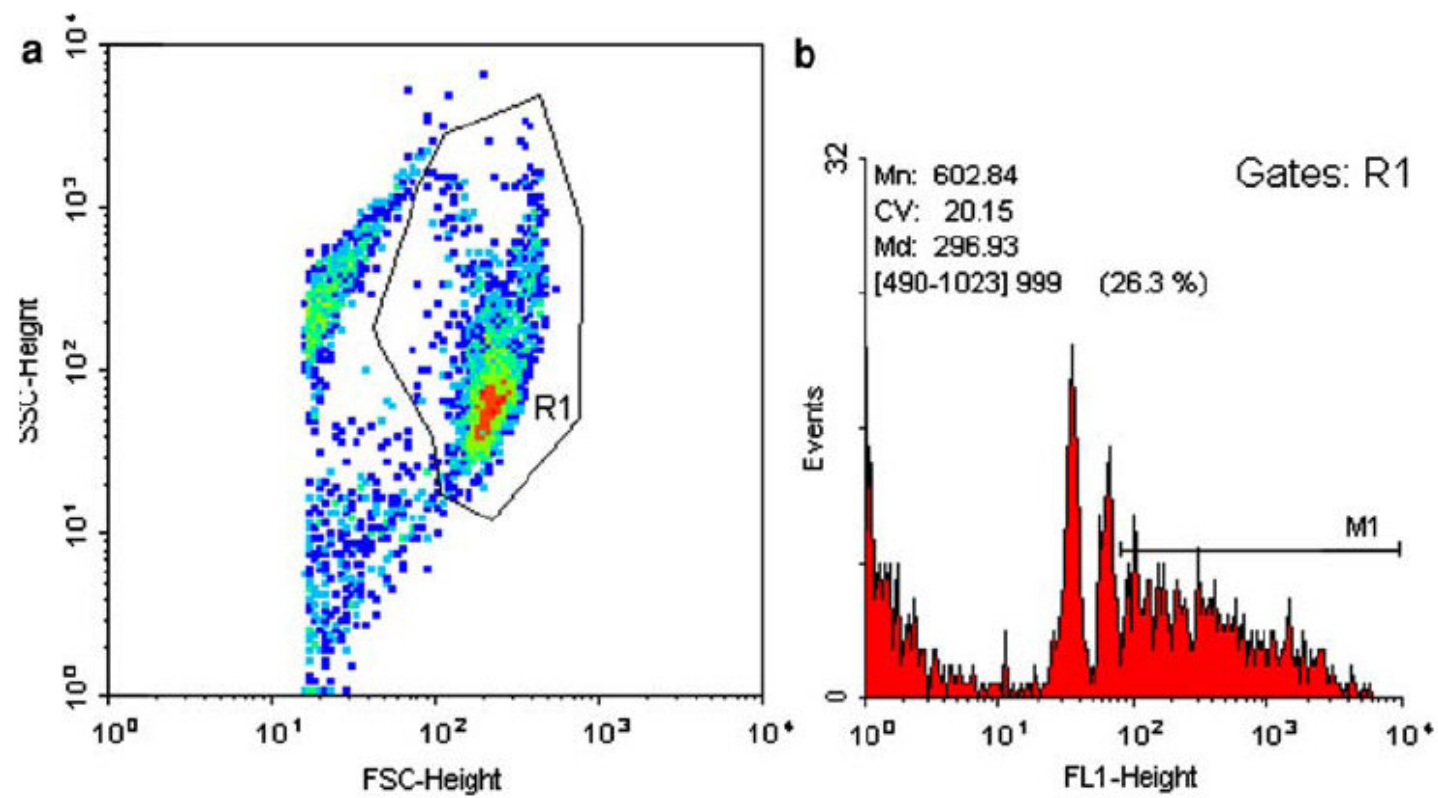

Fig. 2 Example of FLow cytometer results for the phagocytosis assay: a side scatter (SSC, cell complexity) versus forward scatter (FSC, cell size) of hemocytes. Region R1 corresponds to hemocytes, b FL1 Fluorescence of cells belonging to the R1 region showing peaks corresponding to one, two, three, etc. beads. $M 1$ cells showing more than two beads. Here M1 = 999 corresponding to $26.3 \%$ of the total number of hemocytes in this sample $=\%$ phagocytosis. 


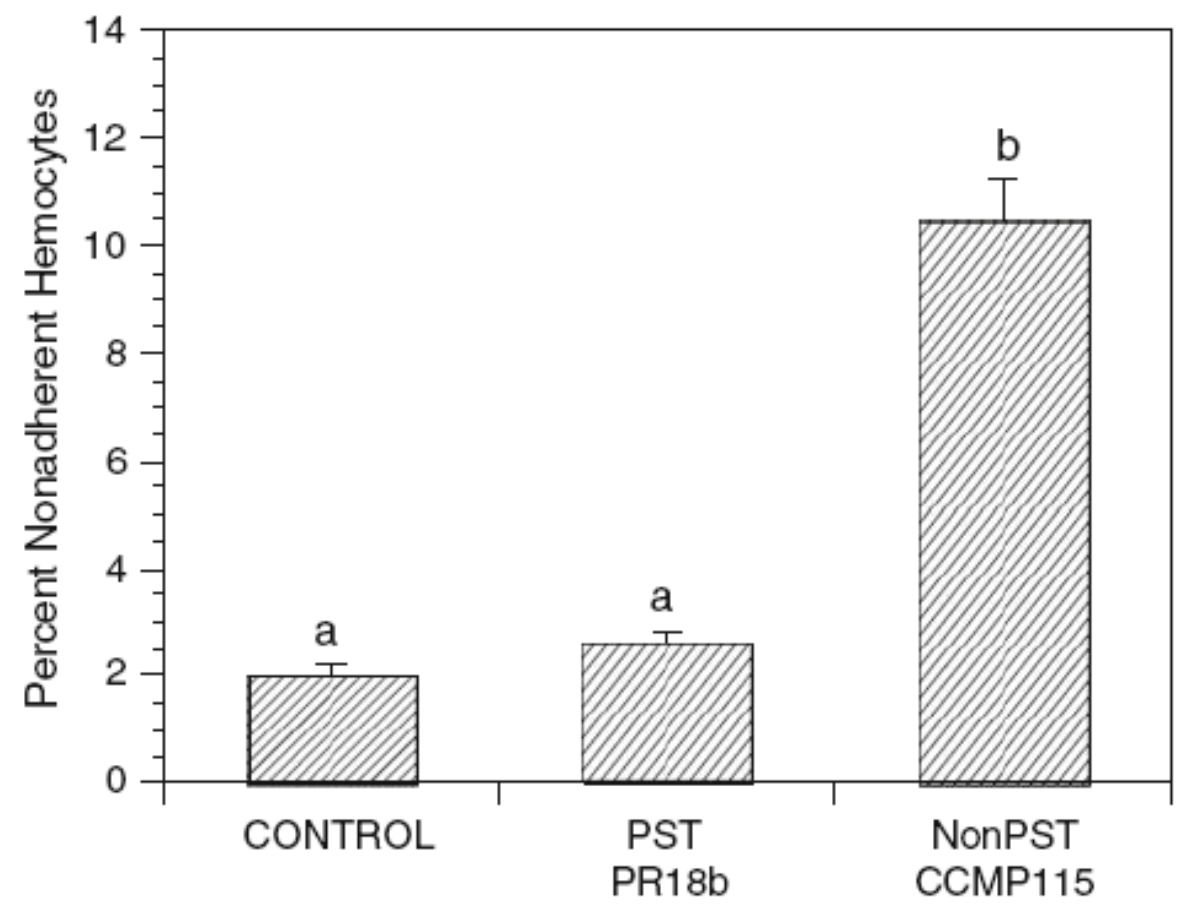

Fig. 3 Mean \pm sem percent nonadherent hemocytes of the softshell lam, Mya arenaria, exposed for $3 \mathrm{~h}$ in vitro to extracts from PSTproducing and nonPST-producing strains of the dinoflagellate, Alexandrium tamarense (Experiment 1). $N=12$ replicate wells from a pooled sample from seven clams for the PST and nonPST producing treatments, and six wells for the controls incubated in filtered seawater. Different letters above the bars indicate differences at the $\alpha=0.05$ level of significance

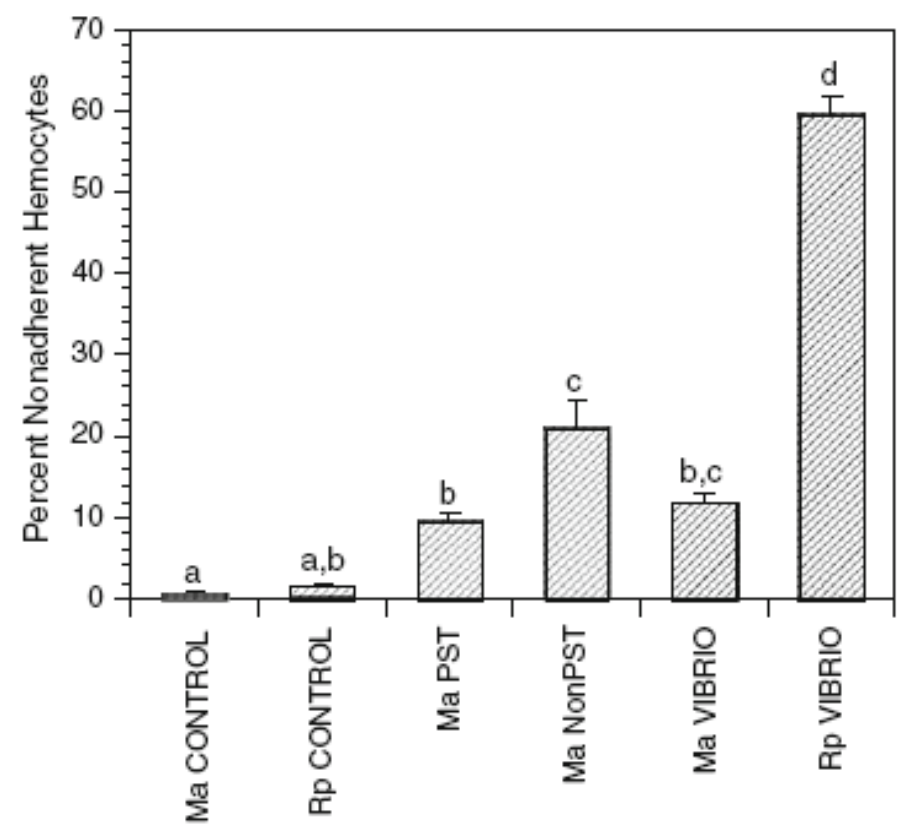

Fig. 4 Mean \pm sem percent nonadherent hemocytes exposed in vitro to extracts from PST-producing and nonPST-producing strains of the dinoflagellate Alexandrium tamarense and intact bacteria, Vibrio tapetis (Experiment 2). Hemocytes pooled from seven softshell clams, Mya arenaria, were exposed to the algal extracts and the bacteria; hemocytes pooled from three Manila clams, Ruditapes philippinarum, were exposed to the bacteria only. $N=12$ replicate wells for the PST and nonPST producing treatments, six wells for the $M$. arenaria controls and the bacterial treatments, and three wells 


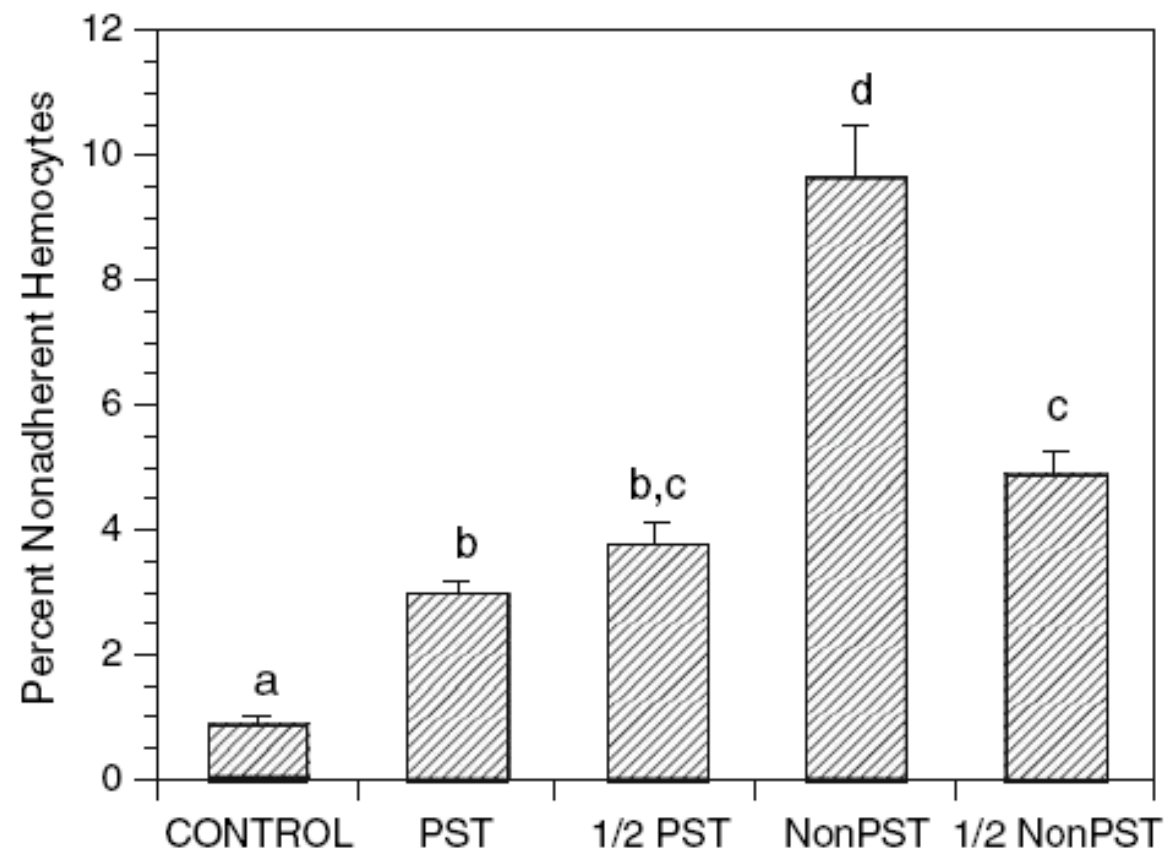

Fig. 5 Mean \pm sem percent nonadherent hemocytes of the Manila clam, Ruditapes philippinarum, exposed for 3 h in vitro to extracts from PST-producing and nonPST-producing strains of the dinoflagellate, Alexandrium tamarense (Experiment 3 ). $N=5$ replicate wells for the $1 / 2$ nonPST and the controls, and 6 wells for the other treatments. Letters above the bars as in Fig. 3 

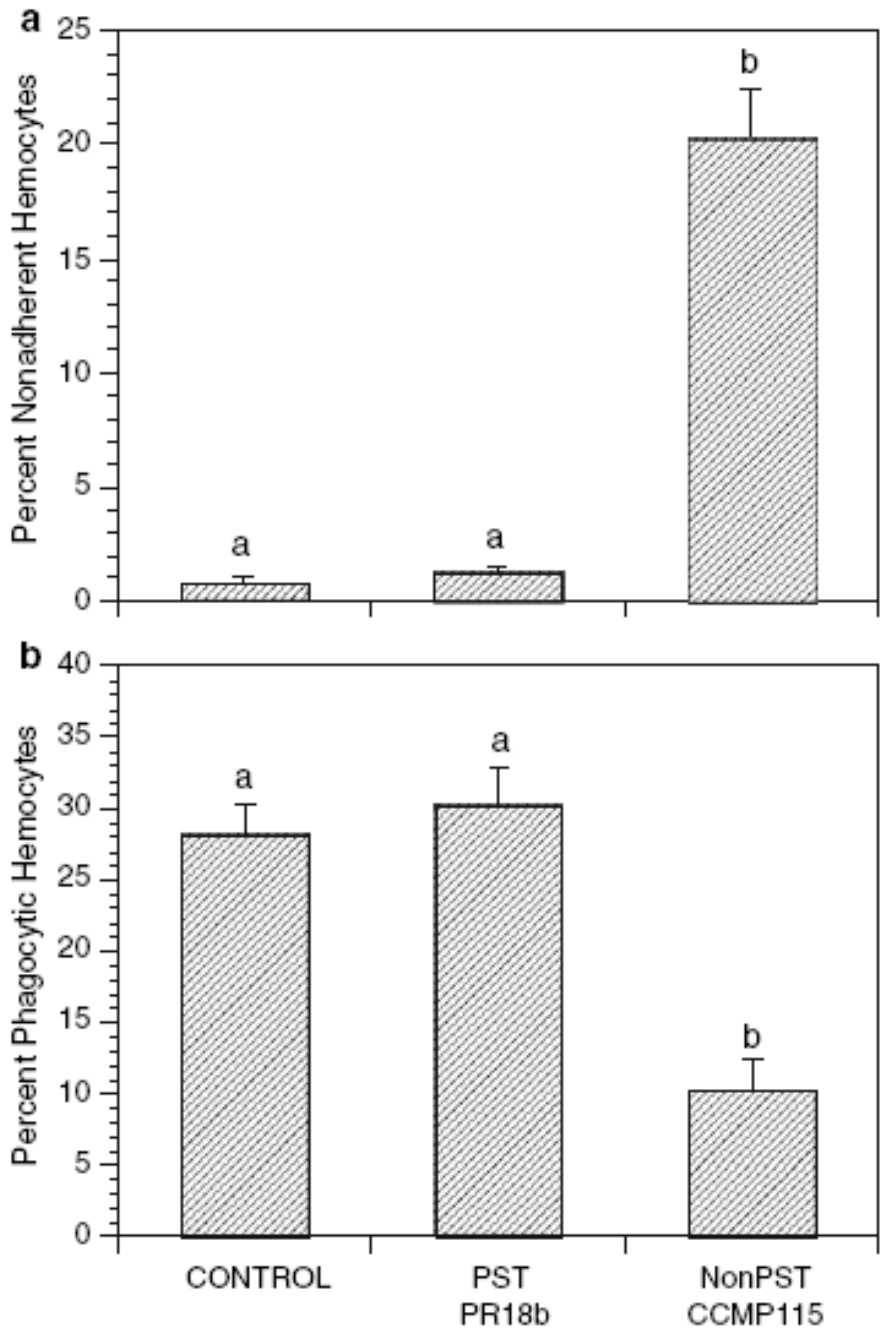

Fig. 6 Mean \pm sem percent nonadherent (a) and phagocytic (b) hemocytes of the softshell clam, Mya arenaria, exposed for $3 \mathrm{~h}$ in vitro to extracts from PST-producing and nonPST-producing strains of the dinoflagellate, Alexandrium tamarense (Experiment 4). $N$ $=12$ individual clams for each treatment and control. The same clams were used for both assays. Letters above the bars as in Fig. 3 

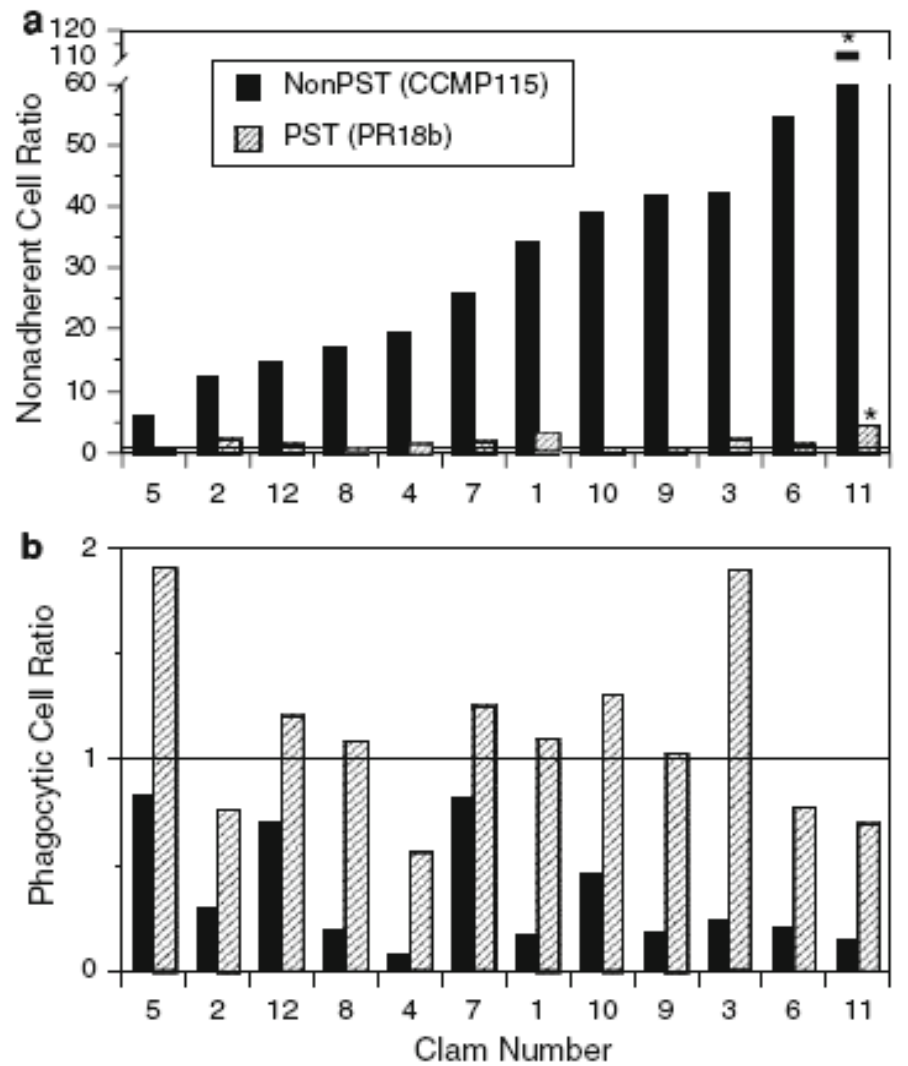

Fig. 7 Nonadherent (a) and phagocytic (b) cell ratios for individual Mya arenaria exposed for $3 \mathrm{~h}$ in vitro to extracts from PSTproducing and nonPST-producing strains of the dinoflagellate, Alexandrium tamarense (Experiment 4). Ratios were obtained by dividing the treatment value by the control value for the same clam. The horizontal line at 1 represents a value identical to the control for that individual. Asterisks indicate values above 2 standard deviations from the mean 

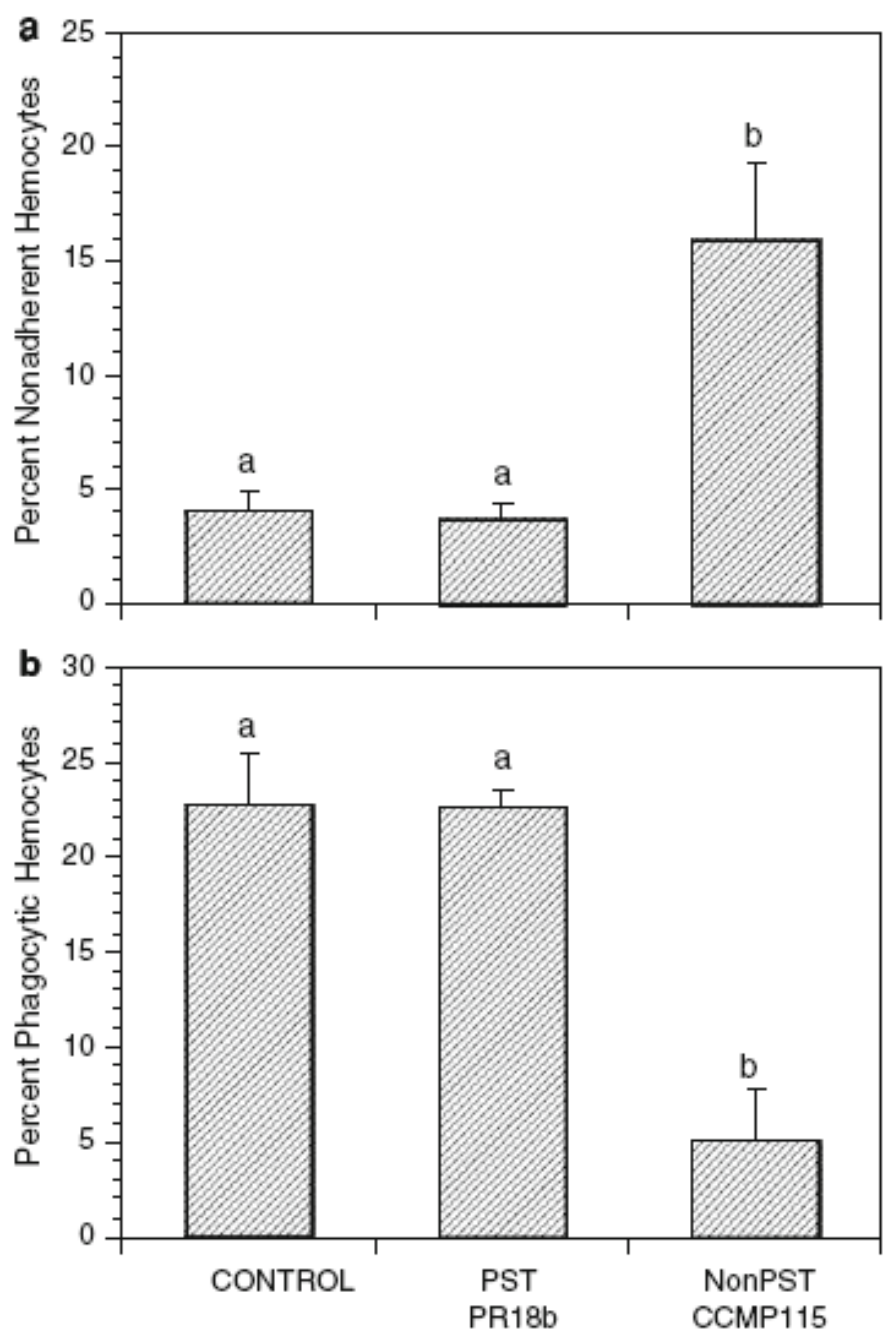

Fig. 8 Mean \pm sem percent a nonadherent and b phagocytic hemocytes of the Manila clam, Ruditapes philippinarum, exposed for 3 $\mathrm{h}$ in vitro to extracts from PST-producing and nonPST-producing strains of the dinoflagellate, Alexandrium tamarense (Experiment 5). $N=12$ individual clams for each treatment and control. The same clams were used for both assays. Letters above the bars as in Fig. 3 

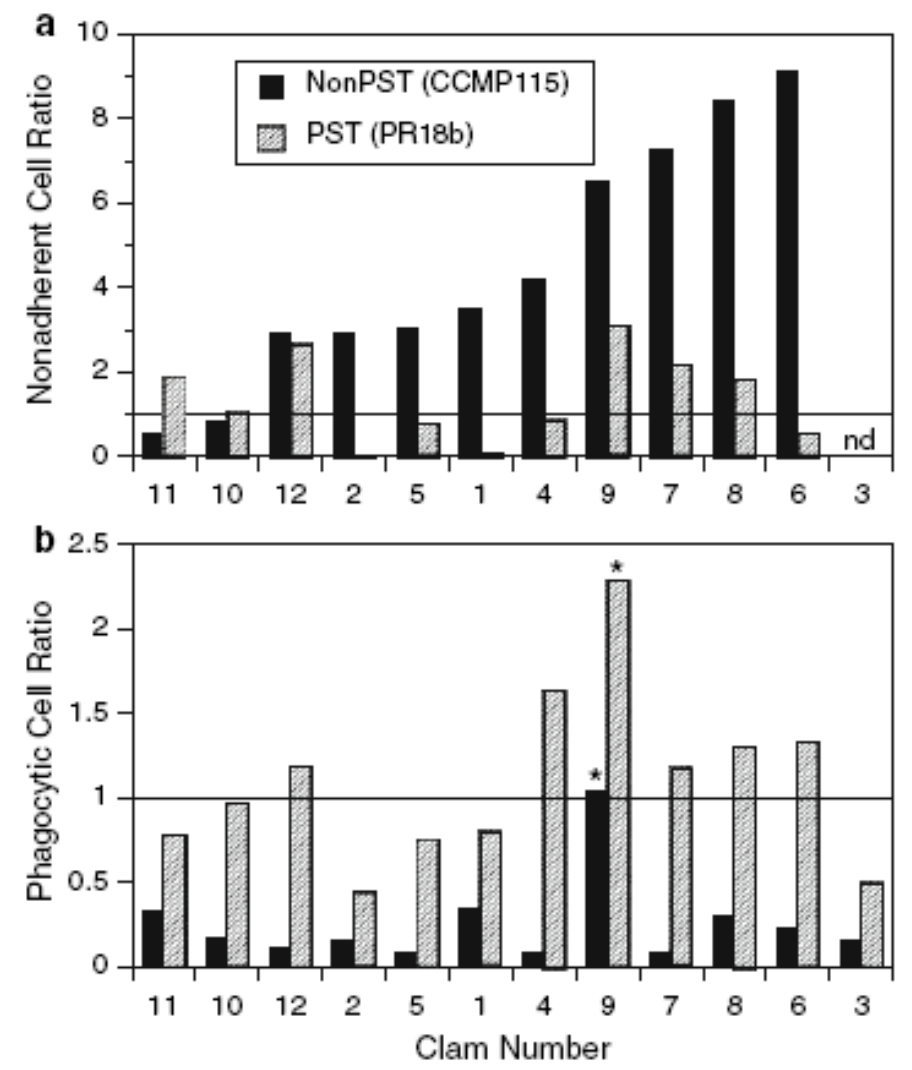

Fig. 9 Nonadherent (a) and phagocytic (b) cell ratios for individual Ruditapes philippinarum exposed for $3 \mathrm{~h}$ in vitro to extracts from PSTproducing and nonPST-producing strains of the dinoflagellate, Alexandrium tamarense (Experiment 5). Ratios were obtained by dividing the treatment value by the control value for the same clam. The horizontal line at 1 represents a value identical to the control for that individual. Asterisks indicate values above 2 standard deviations from the mean. $n d$ no data 